\title{
Sosialisasi Tata Cara Promosi Kepada Pelaku UMKM Di UP2K Lanjung Uma, Kelurahan Alalak Utara, Kecamatan Banjarmasin Utara, Kota Banjarmasin
}

\author{
Nurul Hayati \& Norbaiti \\ Sekolah Tinggi Ilmu Ekonomi Indonesia Banjarmasin \\ Email:nurul@stiei-kayutangi-bjm.ac.id
}

\begin{abstract}
This community service took the topic of the Socialization of Promotion Procedures to MSME Players at UP2K Lanjung Uma, Alalak Utara Village, North Banjarmasin District, Banjarmasin City. The implementation of this community event is by providing socialization on the procedures for business promotion. The goal is that MSMEs at UP2K Lanjung Uma, Alalak Utara Village, North Banjarmasin District, Banjarmasin City, can increase the percentage of sales. This community service program funded by STIE Indonesia Banjarmasin is Rp. 5,000,000. The first week of implementation stages, the location survey at UP2K Lanjung Uma. The second week, held an interview about business motivation and entrepreneurship. The fourth week, provides counseling about, determining market segments and promotion procedures. The fifth week of evaluation of outreach and training. The results of the activity team's observations, first obtained that the training and guidance participants understand marketing management especially the process / quality of production, promotion, packaging and health. Second, the participants can determine target consumers. Third, the quality of their production participants is maintained and the waste does not damage the environment. Fourth, media promotion with online social media. Fifth, providing facilities and infrastructure, such as glass cabinets or storefronts so that it is easier to display products.
\end{abstract}

Keywords: Product quality, promotion and target consumers

\section{Pendahuluan}

\subsection{Latar Belakang}

Di era modern ini pemikiran manusia semakin berkembang. Kemajuan dan perubahan yang terjadi baik dalam bidang sosial, budaya, politik dan ekonomi, berpengaruh terhadap pola perilaku manusia. Manusia berlomba-lomba memikirkan cara untuk membantu mereka dalam mencapai segala tujuan dan kebutuhannya. Hal tersebut berakibat persaingan semakin ketat, terutama dalam dunia bisnis (Akbar, 2018). Dan persaingan yang ketat ini memerlukan strategi promosi yang tepat pula agar dapat bersaing.

Kegiatan promosi merupakan bagian penting untuk meningkatkan citra dan produk perusahaan dalam mencapai keuntungan. Tujuan pokok kegiatan promosi adalah untuk meningkatkan sesuatu sehingga menjadi lebih banyak, lebih tinggi, lebih bermutu, lebih laku, dan sebagainya. Kecenderungan tersebut diikuti dengan meningkatnya varianvarian produk baru serta pergeseran perilaku pasar yang menuntut kegiatan promosi setiap jasa atau hasil produksi secara lebih agresif untuk mempengaruhi pelanggan (Ardhoyo, 2013).

UP2K Lanjung Uma, Kelurahan Alalak Utara, Kecamatan Banjarmasin Utara, Kota Banjarmasin, merupakan salah satu UP2K yang menampung para pelaku UMKM di RT 
18 Kelurahan Alalak Utara, di bawah pengawan TP PKK Kota Banjarmasin.

Setelah mengadakan survey, tim pengabdian masyarakat STIE Indonesia Banjarmasin memutuskan untuk memilih pelaku UMKM di UP2K Lanjung Uma, Kelurahan Alalak Utara, Kecamatan Banjarmasin Utara, Kota Banjarmasin, sebagai objek untuk sosialisasi tata cara promosi produk.

\subsection{Permasalahan Objek di Pengabdian Kepada Masyarakat}

Dari latar belakang objek pengabdian kepada masyarakat, para pelaku UMKM di UP2K Lanjung Uma masih memerlukan motivasi usaha dan perlu mempelajari segmen pasar mereka agar mereka dapat menyusun strategi promosi yang efektif. Pelaku UMKM di UP2K Lanjung Uma memiliki produk-produk yang dapat menjadi unggulan di kecamatan mereka, namun sangat disayangkan mereka menerapkan strategi yang kurang efektif dalam promosi usahanya. Salah satu alasannya adalah ketidaktahuan para wirausahawan dalam menentukan segmen pasar mereka.

\subsection{Manfaat Yang Diharapkan}

Dalam pengabdian masyarakat ini diharapkan tim dari STIE Indonesia Banjarmasin mampu memberikan sosialisasi tata cara promosi usaha kepada pelaku UMKM di UP2K Lanjung Uma, Kelurahan Alalak Utara, Kecamatan Banjarmasin Utara, Kota Banjarmasin, agar dapat meningkatkan presentase penjualan mereka. Bagi pihak audiens, diharapkan agar setelah kegiatan pengabdian kepada masyarakat ini mereka dapat mengerti dan menerapkan tata cara promosi untuk usaha mereka.

\section{Tinjauan Literatur}

\subsection{Dunia Pemasaran}

Pemasaran adalah suatu sistem keseluruhan dari kegiatan-kegiatan bisnis yang ditujukan untuk merencanakan, menentukan harga, mempromosikan, dan mendistribusikan barang dan jasa, yang memuaskan kebutuhan kepada pembeli. Menurut Kotler (2005) dalam Mongi, Mananeke \& Repi (2013), pemasaran adalah proses sosial dan manajerial dengan mana individu dan kelompok memperoleh apa yang mereka butuhkan dan inginkan dengan cara menciptakan serta mempertukarkan produk dan nilai dengan pihak lain.

Menurut Tjiptono (2008) dalam Mongi, Mananeke \& Repi (2013), dunia pemasaran tidak pernah luput dari yang namanya persaingan, salah satu syarat yang harus dipenuhi suatu perusahaan agar dapat mencapai sukses dalam persaingan adalah berusaha mencapai tujuan untuk menciptakan dan mempertahankan pelanggan. Agar tujuan tersebut tercapai, maka setiap perusahaan harus berupaya menghasilkan dan menyampaikan barang dan jasa yang diinginkan konsumen dengan harga yang pantas. Dengan demikian, setiap perusahaan harus mampu memahami kelangsungan hidup perusahaan tersebut sebagai organisasi yang berusaha memenuhi kebutuhan dan keinginan para konsumen sangat tergantung pada perilaku konsumennya.

Kotler dan Keller (2007) dalam A.D Selang (2013) mengatakan bahwa American Marketing Association (AMA) mendefinisikan manajemen pemasaran sebagai berikut: "Manajemen pemasaran sebagai seni dan ilmu memilih pasar sasaran dan mendapatkan, menjaga, dan menumbuhkan pelanggan dengan menciptakan, menyerahkan, dan 
mengomunikasikan nilai pelanggan yang unggul". Menurut definisi di atas, dapat dikatakan bahwa manajemen pemasaran merupakan suatu proses yang dimulai dari proses perencanaan, pengarahan, dan pengendalian produk atau jasa, penetapan harga, distribusi, dan promosinya dengan tujuan membantu organisasi dalam mencapai sasarannya.

Kotler dan Keller (2007) dalam A.D Selang (2013) mengatakan bahwa pengertian Bauran Pemasaran (Marketing Mix) adalah sebagai berikut: "Bauran pemasaran adalah perangkat alat pemasaran yang digunakan perusahaan untuk mengejar tujuan perusahaannya". Maka, dapat disimpulkan bahwa bauran pemasaran merupakan satu perangkat yang terdiri dari produk, harga, promosi dan distribusi, yang didalamnya akan menentukan tingkat keberhasilan pemasaran dan semua itu ditujukan untuk mendapatkan respon yang diinginkan dari pasar sasaran.

\subsection{Promosi}

Swastha dan Irawan (2008) dalam Mongi, Mananeke \& Repi (2013) mengatakan bahwa Promosi adalah arus informasi atau persuasi satu arah yang dibuat untuk mengarahkan seseorang atau organisasi kepada tindakan menciptakan pertukaran dalam pemasaran. Dapat dilihat bahwa strategi promosi merupakan kegiatan yang direncanakan dengan maksud membujuk, merangsang konsumen agar mau membeli produk perusahaan sehingga tujuan untuk meningkatkan penjualan diharapkan dapat tercapai.

Kotler dan Armstrong (2012) dalam Hedynata \& Radianto (2016) mengatakan bahwa promosi (Promotion) adalah suatu unsur yang digunakan untuk memberitahukan dan membujuk pasar tentang produk atau jasa yang baru pada perusahaan melalui iklan, penjualan pribadi, promosi penjualan, maupun publikasi. Kotler dan Armstrong (2012) mendefinisikan bauran promosi (promotion mix) sebagai perpaduan spesifik alat-alat promosi yang digunakan perusahaan untuk mengkomunikasikan value ke customer secara persuasif dan membangun customer relationships. Terdapat beberapa tata cara promosi, seperti;

- Mengenali pasar dan pelanggan.

- Memilih lokasi untuk pemasaran yang sesuai.

- Memanfaatkan media sosial sebagai platform promosi dan berjualan.

- Menawarkan promo yang menarik.

- Produk dan pengemasannya mengikuti tren dan perkembangan zaman (Olivia, 2019).

Hal-hal tersebut diharapkan dapat diterapkan oleh para pelaku UMKM agar penjualan mereka dapat lebih meningkat.

\section{Metode Pelaksanaan}

Sosialisasi tata cara promosi produk diberikan kepada para pelaku UMKM di UP2K Lanjung Uma, Kelurahan Alalak Utara, Kecamatan Banjarmasin Utara, Kota Banjarmasin, sebagai objek untuk pengabdian kepada masyarakat periode ini. Adapun susunan kegiatan pengabdian kepada masyarakat ini sebagai berikut;

1. Minggu pertama, mengadakan survei lokasi UP2K Lanjung Uma sebagai objek 
pengabdian kepada masyarakat.

2. Minggu kedua, mengadakan wawancara dengan ibu-ibu yang bekerja di UP2K Lanjung Uma sebagai peserta program.

3. Minggu ketiga, memberikan penyuluhan tentang:
a. Motivasi usaha
b. Kewirausahaan

4. Minggu keempat, memberikan penyuluhan tentang:
a. Penentuan segmen pasar
b. Tata cara promosi, seperti;

- Mengenali pasar dan pelanggan.

- Memilih lokasi untuk pemasaran yang sesuai.

- Memanfaatkan media sosial sebagai platform promosi dan berjualan.

- Menawarkan promo yang menarik.

- Produk dan pengemasannya mengikuti tren dan perkembangan zaman (Olivia, 2019).

5. Minggu kelima, melakukan evaluasi terhadap aktivitas-aktivitas yang dilakukan selama pengabdian kepada masyarakat.

Biaya dan Jadwal Kegiatan

\subsection{Anggaran Biaya}

Dalam pelaksanaan program pengabdian kepada masyarakat ini biaya keseluruhan yang diusulkan ke STIE Indonesia Banjarmasin adalah Rp. 5.000.000 dengan rincian sebagai berikut:

\begin{tabular}{|l|l|c|}
\hline No. & \multicolumn{1}{|c|}{ Jenis Pengeluaran } & Biaya (Rp.) \\
\hline 1. & Pelatih & 1.500 .000 \\
\hline 2. & Bahan habis pakai & 1.000 .000 \\
\hline 3. & Peralatan penunjang & 1.000 .000 \\
\hline 4. & Perjalanan & 1.000 .000 \\
\hline 5. & Lain-lain & 500.000 \\
\hline
\end{tabular}




\subsection{Jadwal Kegiatan}

\begin{tabular}{|c|c|c|c|c|c|c|}
\hline \multirow[t]{2}{*}{ No. } & \multirow[t]{2}{*}{ Kegiatan } & \multicolumn{5}{|c|}{ Bulan Ke- } \\
\hline & & 1 & 2 & 3 & 4 & 5 \\
\hline 1. & $\begin{array}{l}\text { Minggu pertama, mengadakan survei } \\
\text { lokasi di UP } 2 \mathrm{~K} \text { Lanjung Uma sebagai } \\
\text { objek pengabdian kepada masyarakat. }\end{array}$ & & & & & \\
\hline 2. & $\begin{array}{l}\text { Minggu kedua, mengadakan } \\
\text { wawancara dengan ibu-ibu pekerja di } \\
\text { UP2K Lanjung Uma sebagai peserta } \\
\text { nrooram }\end{array}$ & & & & & \\
\hline 3. & $\begin{array}{l}\text { Minggu ketiga, memberikan } \\
\text { penyuluhan tentang: } \\
\text { a. Motivasi usaha }\end{array}$ & & & & & \\
\hline 4. & $\begin{array}{l}\text { Minggu keempat, memberikan } \\
\text { penyuluhan tentang: } \\
\text { a. Penentuan segmen pasar }\end{array}$ & & & & & \\
\hline 5. & $\begin{array}{l}\text { Evaluasi pelatihan (mulai proses } \\
\text { pelatihan sampai akhir). }\end{array}$ & & & & & \\
\hline
\end{tabular}

\section{Laporan Kegiatan}

Dari pelatihan dan pembimbingan tata cara promosi yang diberikan kepada para UMKM Di UP2K Lanjung Uma, Kelurahan Alalak Utara, Kecamatan Banjarmasin Utara, Kota Banjarmasin, sosialisasi materi dan diskusi, diadakan evaluasi tentang daya serap peserta terhadap materi yang diberikan. Dari hasil pengamatan tim kegiatan, diperoleh sebagai berikut;

1. Para peserta pelatihan dan bimbingan memahami manfaat melakukan wirausaha.

2. Para peserta pelatihan dan bimbingan memahami pengertian manajemen pemasaran.

3. Para peserta pelatihan dan bimbingan memahami komponen dari Bauran Pemasaran (Marketing Mix).

4. Para peserta pelatihan dan bimbingan memahami manfaat dari segmentasi pasar.

5. Para peserta pelatihan dan bimbingan menyadari pentingnya mengikuti prosedur promosi produk yang baik.

6. Para peserta pelatihan dan bimbingan menyadari pentingnya menentukan lokasi tempat mereka akan melakukan promosi dan penjualan produk mereka.

7. Para peserta pelatihan dan bimbingan menyadari pentingnya menentukan target konsumen. 
8. Para peserta pelatihan dan bimbingan menyadari pentingnya lokasi dan keadaan lingkungan yang bebas dari pencemaran sebagai bagian dari nilai jual suatu produk ketika diadakan promosi.

9. Para peserta pelatihan dan pembimbingan menyadari pentingnya promosi melalui sosial media.

10. Para peserta pelatihan dan pembimbingan mulai membuat merencanakan pembuatan akun sosial media untuk promosi.

11. Para peserta pelatihan dan bimbingan menyadari pentingnya bangunan dan ruangan yang higienis, mudah dibersihkan, dan mudah disanitasi.

12. Para peserta pelatihan dan bimbingan menyadari pentingnya memilih bahan yang baik agar produk menjadi olahan yang baik juga.

13. Para peserta pelatihan dan bimbingan menyadari pentingnya melengkapi produk akhir agar produk akhir menarik, jelas, dan aman sampai konsumen.

14. Para peserta pelatihan dan bimbingan menyadari pentingnya kemasan diberi label yang jelas dan informatif untuk memudahkan konsumen mengambil keputusan.

15. Para peserta pelatihan dan bimbingan memahami bagaimana cara mengemas makanan dan snack sebelum dijual.

16. Para peserta pelatihan dan bimbingan memahami pentingnya menggunakan sosial media sebagai sarana promosi dan berjualan masa kini.

17. Para peserta pelatihan dan bimbingan memahami pentingnya menyediakan tester agar pembeli dapat mencoba terlebih dahulu produk kita dan dapat membantu proses pengambilan keputusan lebih cepat.

18. Para peserta pelatihan dan bimbingan mengerti pentingnya melakukan penitipan produk-produk mereka sebagai rangkaian dari upaya promosi produk ke khalayak ramai.

19. Para peserta pelatihan dan bimbingan memahami pentingnya menyediakan lemari kaca atau etalase agar dapat lebih mudah melakukan display produk.

20. Para peserta telah berhasil menentukan segmen pasar, target konsumen, dan cara promosi mereka sesuai dengan target konsumen yang telah ditentukan.

\section{Kesimpulan}

Dapat disimpulkan dari kegiatan pelatihan dan pembimbingan tata cara promosi yang diberikan kepada para UMKM Di UP2K Lanjung Uma, Kelurahan Alalak Utara, Kecamatan Banjarmasin Utara, Kota Banjarmasin berjalan dengan baik dimana peserta memahami manfaat melakukan wirausaha, mulai dari perencanaan produk sampai dengan pengemasan produk serta pemasaran produk.

\section{Referensi}

Mongi, L., Mananeke, L., \& Repi, A. (2013). Kualitas Produk, Strategi Promosi dan Harga Pengaruhnya Terhadap Keputusan Pembelian Kartu Simpati Telkomsel di Kota Manado. Jurnal Riset Ekonomi, manajemen, Bisnis, dan Akuntansi, 1(4). doi: 10.35794/emba.v1i4.3490

A.D Selang, C. (2013). Bauran Pemasaran (Marketing Mix) Pengaruhnya Terhadap Loyalitas Konsumen Pada Fresh Mart Bahu Mall Manado. Jurnal EMBA: Jurnal Riset 
Ekonomi, Manajemen, Bisnis Dan Akuntansi, 1(3). doi: 10.35794/emba.v1i3.1374

Akbar, F. (2018). Analisis Komparatif Keunggulan Bersaing Berbasis Marketing Mix Berdasarkan Persepsi, Harapan, dan Kepentingan Konsumen Motor Bekas (Studi Kasus Motif Pembelian Motor Honda dan Yamaha di PJBSM Lumajang). Instituional Repository STIE Widya Gama Lumajang. Retrieved from http://repository.stiewidyagamalumajang.ac.id/499/

Hedynata, M., \& Radianto, W. (2016). Strategi Promosi Dalam Meningkatkan Penjualan Luscious Chocolate Potato Snack. Jurnal Performa, 1(1). Retrieved from https://journal.uc.ac.id/index.php/performa/article/view/108

\section{Copyrights}

Copyright for this article is retained by the author(s), with first publication rights granted to the journal.

This is an open-access article distributed under the terms and conditions of the Creative Commons Attribution license (http://creativecommons.org/licenses/by/4.0/) 